\title{
Nature-Based Interventions and Mind-Body Interventions: Saving Public Health Costs Whilst Increasing Life Satisfaction and Happiness
}

\author{
Jules Pretty ${ }^{1, *(D)}$ and Jo Barton ${ }^{2}(\mathbb{D}$ \\ 1 School of Life Sciences, University of Essex, Colchester CO4 3SQ, UK \\ 2 School of Sport, Rehabilitation and Exercise Sciences, University of Essex, Colchester CO4 3SQ, UK; \\ jobarton@essex.ac.uk \\ * Correspondence: jpretty@essex.ac.uk
}

Received: 17 September 2020; Accepted: 20 October 2020; Published: 23 October 2020

\begin{abstract}
A number of countries have begun to adopt prevention pays policies and practices to reduce pressure on health and social care systems. Most affluent countries have seen substantial increases in the incidence and costs of non-communicable diseases. The interest in social models for health has led to the growth in use of social prescribing and psychological therapies. At the same time, there has been growth in application of a variety of nature-based and mind-body interventions (NBIs and MBIs) aimed at improving health and longevity. We assess four NBI/MBI programmes (woodland therapy, therapeutic horticulture, ecotherapy/green care, and tai chi) on life satisfaction/happiness and costs of use of public services. These interventions produce rises in life satisfaction/happiness of 1.00 pts to 7.29 ( $n=644 ; p<0.001$ ) (for courses or participation $>50 \mathrm{~h}$ ). These increases are greater than many positive life events (e.g., marriage or a new child); few countries or cities see +1 pt increases over a decade. The net present economic benefits per person from reduced public service use are $£ 830-£ 31,520$ (after 1 year) and $£ 6450-£ 11,980$ (after 10 years). We conclude that NBIs and MBIs can play a role in helping to reduce the costs on health systems, while increasing the well-being of participants.
\end{abstract}

Keywords: nature-based interventions; mind-body interventions; life satisfaction; happiness; green social prescribing

\section{Introduction}

\subsection{Prevent to Save}

Recent decades have seen substantial improvements in a wide range of health indicators in populations of affluent countries, resulting in better infant survival, more effective treatments of cancers and infectious diseases, and greater longevity [1-3]. At the same time, however, a suite of non-communicable diseases (NCDs) have increased in incidence across whole populations, the most costly comprising mental ill health, dementias, obesity and type 2 diabetes, loneliness and cardiovascular disease (including strokes) [4-7]. NCDs worldwide now constitute more than $50 \%$ of annual deaths. As a result of both unhealthy longevity and expansions in incidence of these NCDs, public health and social care systems have been facing growing financial pressure on services [8,9].

The UK Chief Medical Officer [10] proposed that these health costs arising from ways of living required a "new canon for prevention." With an ageing population, growing numbers of people with long-term health conditions (LTCs), cost inflation, and pressures on revenue funding, the health systems in affluent countries need to find ways to invest in prevention to slow the pipeline of people requiring primary and secondary treatment. This concern for prevention is, of course, not new: in 1736, 
Benjamin Franklin wrote that "an ounce of prevention is worth a pound of cure" (referring specifically to fire safety), and since then, the axiom has been widely used in reference to health systems. What has changed recently in affluent countries has been the scale of costs and the pressing need for changes to policy and investment priorities. In the UK, the prevention pays policy was expanded in 2018 while setting out ambitions for system-wide changes by 2040 [8,11], with a raised focus on health as an asset that needed protecting: "prevention creates the right conditions for good health and wellbeing helping everyone to live well for longer" [12]. There is a need, in short, to focus on "prevention to slow the growth in demands on the National Health Service (NHS)", making it sustainable for future generations [12].

The annual direct costs of NCDs is now a substantial personal and economic burden. Poor diet, physical inactivity, fractured social structures, lack of access to green spaces and consumption of alcohol and recreational/prescription drugs, combined with some genetic factors, have resulted in a sharp increase in costs of NCDs [3]. In the UK, the cost to the NHS of six NCDs has been calculated to be some $£ 62$ billion per year, with the full cost to the whole economy at $£ 160$ billion $[6,13]$. The treatment costs of these conditions thus represent $35 \%$ of the annual revenue (running) costs of the NHS ( $£ 177$ billion, 2019-2020). It has been estimated that $15 \mathrm{M}$ people in the UK (23\% of the population) suffer from long-term health conditions (LTCs) [8], and these people make up 50\% of GP (general practice) appointments and 70\% of hospital inpatient days. Many LTCs are mental ill health related, often termed the diseases of despair.

Successful public health responses at the population level remain rare. Exceptions include mass vaccination programmes, the removal of lead from petrol (1980s-1990s), the growing legal and cultural restrictions on tobacco (resulting in a 20 year drop in incidence from $30 \%$ of adults to $17 \%$ by 2018), the increasing numbers of participants in Park Runs (from 2004 up to 350,000 participants weekly). The Covid-19 self-isolation and lockdown programmes common to many countries in 2020 represent the largest ever cost-prevention programmes imposed by public policy.

Here we assess the potential value of social models for health, in which changed behaviours and choices of individuals could create the conditions by which they stay happier and healthier for longer in life. Our focus is on nature-based and mind-body interventions (NBIs and MBIs), and how adoption could lead to reduced cost pressure on health and social care and other public services.

\subsection{Social Models of Health}

In the past two decades, it has become clear that the structure of the social, ecological and economic environments in which people live and work is an important shaper of health and well-being outcomes. This has been called a "social model of health" [8]. It has also become apparent that growth in average national income, as measured by GDP per capita, does not result in increases in life satisfaction/happiness above a GDP per capita threshold of between $\$ 10$ and 20,000 [6,14-17]. This Easterlin paradox $[18,19]$ suggests that (i) life satisfaction/happiness (LS/H) may be influenced by non-material behaviours and choices in the economy, and that (ii) GDP is a poor measure of well-being and happiness once basic needs have been met [17,20-22].

In most affluent countries, including the UK, GDP per capita has increased several fold over half a century, yet LS/H at the population level has remained persistently stable $[14,15,17]$. Individuals have more stuff (material goods), but these have not made each person on average happier [15,23]. It is clear that uncosted activities are influencing $\mathrm{LS} / \mathrm{H}$, and so not included in the measures and assumptions about the economic success of countries; it is also clear that overcosted activities are included in GDP where they clearly result in negative health outcomes (e.g., air pollution or road traffic accidents). Recent evidence has also shown that net well-being (life satisfaction/happiness) across populations is reduced when inequality grows [24,25], and where there is breakdown of social structures and support [26], lack of access to natural and green spaces [27,28], and consumption of unhealthy foods [29].

One example of a modern non-communicable disease affected by the breakdown of social structures is loneliness [30-32]: it has an acute negative effect on health (equivalent to smoking 15 cigarettes 
daily), and increases annual GP visits by 1.8 -fold and annual accident and emergency (A\&E) visits by 1.6 -fold [8]. Loneliness and social isolation increase mortality by $25-30 \%$ over 7 years [33]. At the same time, it is clear that the socially connected live longer and are happier [34], and countries with higher levels of trust in other people are happier $[17,22]$. Volunteers who contribute to the well-being of others and to the quality of lived environments tend to have healthier lifestyles, lower incidence of mental ill health, and live longer [17,35-37].

The presence of green and accessible natural space is also known to be important to incidence of NCDs. Green space close to residence reduces mortality [38], reduces levels of stress hormones [39], increases levels of physical activity [40], changes dietary decisions and habits [29,41], and affects longevity of the elderly [42]. Regular exercise and rich social networks add 5.4 years to life [43], walkers live longer [44] and healthy plant-based diets play a key role in reducing mortality $[29,41,45]$. It is also clear that life satisfaction and happiness plays a direct role in longevity [17,22]. The happiest third of the population aged $>50$ have a $10 \%$ chance of dying over the next 9 years, the middle third a $20 \%$ chance, and the least happy a $30 \%$ chance [46].

A range of prospective life-course studies and large-scale evaluations (e.g., Caerphilly, Dunedin, Maudsley/Cambridge cohorts, Milwaukee nuns, Harvard ageing, and New England centenarians) have further shown how combinations of choices about behaviours and consumption patterns directly affect health and well-being over many decades [4,42,47-51], how the structure of natural and social environments shape health, and how the value of early interventions demonstrated by studies of children whose adult health and well-being outcomes are improved when exposed to activities in natural places (playgrounds, gardens, and woodlands) [52-54].

\subsection{Social Prescribing and Psychological Therapy Models}

The UK health system has developed two important "prevention pays" intervention models in recent years. Social prescribing (SP) was developed by GP surgeries to offer alternatives to medical intervention (NASP, 2019), and the Improving Access to Psychological Therapies (IAPT) programme provides novel interventions for patients with depression and anxiety $[55,56]$. These have been called non-clinical community interventions (NCCIs) [57], and are particularly focused on people and patients with NCDs. Both types of intervention now provide valuable data on costs and beneficial outcomes for individuals and health systems.

Social prescribing is a relatively recent term applied to the systems of referral used by GP primary health care operators. It has been defined as "supporting people via social prescribing link workers to make community connections and discover new opportunities, building on individual strengths and preferences, to improve health and well-being" [58]. The longest serving SP operation is at Bromley-by-Bow (25 years), and there are exemplars acknowledged in Brighton, Doncaster, Dudley, Frome, Leeds, London (City and Hackney, Croydon, Tower Hamlets), Newcastle, Rotherham, and Yorkshire and Humber [57-64]. The most effective SP programmes employ Link Advisers as guides to patients, interviewing and assessing needs, and then ensuring they can take advantage of the community-based options available with good signposting. These fall into distinct categories: (i) for advice and knowledge (e.g., on benefits or housing); (ii) for skills development (e.g., computing, food and cooking); (iii) for activities in social groups (e.g., befriending and self-help groups, dance, art, or crafts); and (iv) for activities with therapeutic design, especially nature-based (e.g., walking for health or woodland therapies) and formal counselling. Most well-developed SP operations have $>50$ options for onwards patient referral; some have more than 200 options (e.g., Bromley-by-Bow).

The National Academy for Social Prescribing (NASP) was established by the NHS in 2019, and is seeking to expand SP as a new social movement [58]. The NASP notes that SP is part of an aim to prescribe bespoke personalized medical and social interventions, but also note that health improvements may be "long slow journeys" for many patients. The term green prescribing has been used to refer to the nature-based options available to SP operations $[65,66]$. 
The Improving Access to Psychological Therapies (IAPT) programme was established in 2008, and a range of talking and cognitive therapies are now recommended by National Institute for Health and Care Excellence (NICE). These include cognitive behavioural therapy (CBT), interpersonal psychotherapy, couples therapy, counselling, psychodynamic therapy and mindfulness-based cognitive therapy $[55,56]$. These are offered to address a wide range of mental health conditions such as depression, general anxiety disorder, post-traumatic stress disorder (PTSD), panic disorders, obsessive-compulsive disorder, and body dysmorphic disorder. Some 560,000-600,000 patients are treated each year, with full recovery rates of $40-50 \%$ recorded, and some $67 \%$ of people making "reliable improvements" [12,55,67,68]. These efficacy rates are better than most reported uses of antidepressants $[69,70]$. IAPT made $1.6 \mathrm{M}$ referrals for talking therapies in 2019-1.09 M started courses, and 52\% completed courses $(583,000)$, with a range of 7-20 sessions attended per person [67].

Evaluations of SP programmes have measured reductions in GP visits (by $12 \%$ per person over 6 months, by $28 \%$ over 12 months); falls in A\&E visits (by $24 \%$ over 1 year); reductions in secondary care appointment (down by $35 \%$ over 1 year). For each $£ 1$ invested in SP, benefits are $£ 1.43$ ( 3 months); $£ 2.30$ ( 1 year); $£ 1.98$ ( 5 years); and reduced costs of the order of $£ 250-500$ per person per year. The Healthy London partnership for Social Prescribing has noted that London could have saved $£ 110 \mathrm{M}$ over 2013-2016 if SP had been widely available and used.

\subsection{Nature-Based Interventions (NBIs) and Mind-Body Interventions (MBIs)}

It is now well established that exposure to nature has positive health and well-being benefits. There has been a rapid expansion in evidence, showing in a wide variety of contexts that green exercise (physical activity in the presence of nature) improves health and well-being [13,17,71,72]. Every social group benefits: all ages, genders, ethnicities and social classes respond positively to green exercise. All natural environments have been found to be beneficial: from urban parks to biodiversity rich, from small local to large landscapes, from domestic gardens to the farmed and wild landscapes $[40,73]$. The phrase dose of nature was coined to indicate that exposure to green exercise is analogous to a medicinal dose, improving mental health and well-being in the short and long term [74-76].

The natural environment is now understood to provide vital health services as well as other ecosystem services [77,78]. In 2019, the UK's 25 Year Environment Plan published by the government [79] set out six priorities, one of which was to "connect people with environments to increase health and well-being", and substantial focus has been put on making use of green spaces and natural habitats to improve the health of whole populations. A wide range of nature-based interventions (NBIs) have been developed across conservation, wildlife and community organisations and charities [72,80-85]. These natural and social therapies have been deployed for groups under mental stress, at-risk children and young people, refugees, probationers, and dementia sufferers [65]. Fields in Trust [86] show that parks and green spaces provide some $£ 34$ billion of health and well-being benefits annually, saving the NHS $>£ 100$ m per year; the benefits equate to $£ 974$ per person per year to replace life satisfaction gained from local parks and green spaces.

Notable programmes for NBIs include (i) forest and woodland schools [87,88]; (ii) wilderness and adventure therapies [89,90]; (iii) ecotherapies and green care [91,92]; (iv) social farms and gardens [65]; (v) dementia prevention and treatment $[93,94]$ walking for health (Walking the Way to Health set up 500 walking groups for some 170,000 people [80]).

At the same time, a wide range of mind-body interventions and practices (MBIs) have become popular, usually delivered by individual trainers or community groups. Many millions of people practice yoga, tai chi and other forms of mindfulness, either individually or with groups, and often in natural environments (tai chi/qigong- $65 \mathrm{M}$ daily practitioners in China, $7.5 \mathrm{M}$ in the USA). The evidence base on health impacts is substantial. There have been $>500$ studies of the health benefits of tai chi, mindfulness, yoga and qigong on tens of thousands of participants [95-106]. Following a mix of periods of practice (short to medium courses, short- to long-term adoption), these have resulted 
in improvements to bone density, cardiopulmonary function, reduced body mass, reduced anxiety, and improved quality of life.

In both NBIs and MBIs, the key behaviour (and later habit when automated without thought) that affects life satisfaction and happiness is the practice of attentiveness and immersion $[13,107,108]$. This can produce altered states of mind [109-111], also called flow [112], resulting in a downregulation or quieting of the mental chatter that is a common source of anxiety and mental ill health [113]. We have proposed a simple brain metaphor, with levels representing different stages of mammal-hominid evolution; see [13,114-116]. The brain stem (bottom brain) is the oldest and contains survival functions: it is fast responding, involuntary, automatic, impulsive, driven by emotions, and is the executor for habits and routines. The top-brain cortex is the most recent, having expanded in size rapidly during the later stages of hominid evolution: it is slower, voluntary, able to learn and plan, and contains centres for social abilities of empathy and language. The top brain is calming, drives the parasympathetic nervous system (PNS), and is characterised by rest and digest. The bottom brain is spiked into action by the amygdala, the sentinel for threats, drives the sympathetic nervous system (SNS), and is characterised by fight and flight.

There is, though, no off switch for the thinking part of the pre-frontal cortex. This default mode can only be downregulated by choices we make with the body. Attentiveness and immersion (A\&I), also called the relaxation response (RR) $[117,118]$, have been shown to induce transient hypofrontality in the brain's default mode network (DMN) [119-123]. The relaxation response can also build grey matter, particularly in the hippocampus and thus increasing memory; this induction of the RR by MBIs moderates the expression of 3800 genes [118], changing the internal responsiveness to stressors. Systematic reviews have shown the reduced expression (downregulation) of genes involved in inflammatory reactions, reducing risk of inflammation and related diseases [124,125]. In this way, NBIs and MBIs reduce the effects of stress, increase well-being and reduce anxiety, depression and pain.

\subsection{Theory of Change for Interventions}

Two questions are central to the success of all non-clinical community interventions (NCCIs: SP, IAPT, NBIs and MBIs): (i) does the intervention result in measurable health and well-being benefits, and (ii) does the intervention induce the adoption of repeated habits that result in long-term positive outcomes and prevention of costs? Most interventions focus more strongly on the former (core design components of the intervention), and many pay no attention to the nature of habit formation. A common aim of all interventions should be to shift personal behaviours and choices towards easily repeatable daily actions that lead to sustained improvements in health and well-being. An effective dose of nature, for example, was shown in a meta-analysis [74] to be highly effective in improving mental health and well-being in the first five minutes of exposure in a green space. However, this alone will not produce permanent changes in neural structure unless it provokes behaviours and habits that individuals can easily repeat $[113,126]$.

Habits are fixed action patterns (FAPs), producing automated behaviour or thought patterns without intention. Triggers may be external or internal, and result in behaviours proceeding to completion once initiated. Well-practised behaviours recur because performance has become automated, thus saving the brain from using resources [127]. Habit strengths are higher if repeated, so that they do become involuntary [128], and then hard to change [129,130]. Adherence is a key hope for the application of all NCCIs: an immediate benefit from a short-lived activity can increase life satisfaction, but permanent changes to brain and body will only occur from repeated practice [131-133].

As indicated above, planning and learning occurs in the pre-frontal cortex (PFC) of the brain, and as routines are automated so they are sent downwards to the mid and lower brains, and tend to remain fixed unless brought back up for amendment [13]. As a routine is habituated, so the basal ganglia take over from the PFC, allowing us to pay less attention (and the brain to use less energy). All habits require many hours of practice, but once learned no longer require active attention (for example, walking gait and language). Many of the modern conditions of ill health result from behaviours gradually adopted 
over time and are thus hard to change, including eating and drinking habits, smoking, sedentary lifestyles, reduced direct contacts with family and community, reduced contact with green places, and increased use of pharmaceutical solutions to ill health.

In the increasingly typical modern life course, many people cede territory, inch by inch, to automated behaviours and habits that often bring discontent, unhappiness and ill health. We pay less attention to eating well, forget friendship groups, and become less active. Yet new habits and behaviours need forceful and sometimes fierce action, not least because there are economic and social structures that many people cannot avoid (e.g., design of lived environments and housing) or are actively encouraged by companies and advertising to adopt (e.g., consumption of unhealthy foods and drink or gambling). This is the social model of health-the contexts of lived circumstances shape health outcomes, often without people appreciating the influences.

There are thus many economic and social influences that are beyond the capabilities and responsibilities of both individuals and delivery organisations. It is not a matter of choice that individuals are in some way unwell before referral, nor that they may be out of work or lacking safe housing options, not whether they have fallen into health-damaging and socially costly habits (such as with alcohol or recreational drugs). It is well established that living within $1 \mathrm{~km}$ of urban green space improves well-being and healthy longevity [42], yet many people may face physical and cultural barriers that prevent access to such green space. It is well known that five fruit and vegetable portions eaten daily improves health in the long term $[134,135]$, yet $20 \%$ of the UK adult population consumes zero portions daily [136]. Corporate advertising encourages adults and children to consume unhealthy foods, which are often cheaper and more available than healthy options owing to the nature of the food system [137]. Ambient air pollution affects health, yet individuals are mostly unable to avoid pollution and its effects in the short term (unless by moving location or effectively lobbying for policy change). It is within these contexts that nature- and social-based interventions must act.

Experimental research has shown that it takes 28 to 84 days to form a habit, depending on the time devoted each day $[126,133]$. We have thus suggested a heuristic (rule of thumb) of $50 \mathrm{~h}$ of practice to hardwire a new habit (equivalent to 50 days at one hour per day, or 100 days ( 3 months) at half an hour per day) [13]. A period of intense cognitive engagement occurs while learning the habit (high activity in the PFC), and is then followed by the shift of the new routines to the basal ganglia. The habit is then automated without thought. However, changing ingrained habits is hard: we have to force the body to do something different, as it will not choose voluntarily to do so.

These habits may be developmental (learning to walk as a toddler, handwriting, learning to drive a car) or deliberative (creating new behaviours for well-being, such as diets or giving up smoking). The $50 \mathrm{~h}$ benchmark represents the period of active cognitive engagement with the new activity. Many habit-forming programmes (such as diets) do not persist for long enough to form new neural structures, and are thus doomed to fail in the long term. The cravings of habits are hard to overcome [113]: having made the effort to learn and adopt, the brain does not wish to devote valuable resources to dispose of old habits and develop new ones.

Thus a theory of change for effective programmes of social and green interventions (by NBIs and MBIs) centres on the need for the following key components, following the COM-B model of behaviour change [138,139]:

(i) Opportunity: A logic of adherence-there need to be incentives and motivations for individuals to complete the course or programme.

(ii) Motivation: The ability of individuals to incorporate the new behaviours, habits and activities into their lives beyond the course/programme in order to sustain health and well-being benefits over the long term, resulting in reductions in demand for public health and other public services (e.g., education support, criminal justice actions and support).

(iii) Capability: A programme design that is intended to produce long-term and positive changes in individuals. 


\section{Materials and Methods}

\subsection{Four NBI and MBI Programmes of Intervention}

We have selected four NBI and MBI programmes where data were comparable to assess the impacts of intervention, and use evaluations of both SP and IAPT programmes [12,58,59,61] and measures of life satisfaction/happiness $[21,22]$ to provide external benchmarks.

\subsubsection{Green Light Trust (NBI)}

The Green Light Trust (GLT) is a charity providing natural and social interventions for a wide range of vulnerable groups in the east of England. The GLT supports adults and young people facing challenges in their lives by using nature as the medium for engagement. The Trust supports individuals facing a broad range of challenges including mental health issues, substance misuse, special educational needs, veterans, women and families in a refuge, those in probation services and those most vulnerable and marginalised in or on the periphery of the education system. The GLT delivers woodland therapy to 1500 adults and children each year, and seeks to provide new life-course pathways for the vulnerable and hard to reach in society. Before the advent of Covid-19, this work was predominantly delivered in a natural woodland setting, where social isolation could be addressed whilst increasing confidence, self-esteem and progression in life. The key components of woodland therapy are learning about natural history, craft activities, preparing and cooking food, led discussions and walking in woodlands. This delivery method has been adapted and support is continuing for the adults and young people. In 2020, the GLT developed a blended online delivery model, calling its land-based programmes called Earth, and the online delivery and support called Air.

\subsubsection{Ecominds (NBI)}

The five-year Ecominds project was run by the mental health charity Mind (2007-2012), and benefitted 12,000 people in 130 ecotherapy/green care projects [91,140]. These comprised nature-based interventions in a variety of natural settings. These interventions included some formal therapy (e.g., counselling sessions, cognitive behavioural therapy, or psychotherapy), as well as informal therapy of the programme of NBI activities. The projects were effective in raising mental well-being of participants (all adults), in enhancing social inclusion, vital to the recovery of those living with mental health problems, in both increasing connections with nature, enabling participants to benefit further from the associated health and well-being benefits, in improving well-being and social inclusion, and in leading to the development of healthier lifestyles and environmentally friendly living. Many projects have since continued to provide services for people with mental health challenges: green care components, for example, have been developed into the care farming delivered by 250 operations to 9000 vulnerable people each year [65].

\subsubsection{Trust Links Growing Together (NBI)}

The Growing Together project was established in Westcliff in 2000 by independent local charity Trust Links to address the mental health needs of people living in Southend-on-Sea. This social and therapeutic gardening project supports the recovery and well-being of adults experiencing mental health problems, people with learning disabilities, and people living with other disabilities. The aim was to complement existing clinical services and help people in their recovery journey as they progressed to independence. Trust Links' vision is to provide nurturing and supportive environments to develop strong, resilient and healthy people and communities. Since the flagship site in Westcliff opened in 2000, the Growing Together model has been replicated in three coastal regions of Essex, UK (Shoeburyness in 2012, Thundersley in 2015, Rochford in 2016). Members typically attend 1 to 2 days per week (50-100 times per year) to access therapeutic horticulture as well as a range of peer-support and vocational activities including music, art, creative writing, yoga relaxation, cooking and crafts. Accredited vocational training is provided for work-related qualifications. Trust Links also supports members 
to work towards employment through a Job Club and one-to-one employment support. Across the country, there are some 1000 horticultural therapy projects with 21,000 annual adult and child users [65].

\subsubsection{Living Movement Tai Chi (MBI)}

Tai chi is an ancient form of exercise arranged into set moves and sequences. It is defined as a mind-body exercise rooted in multiple Asian traditions, including martial arts, traditional Chinese medicine, and philosophy. Tai chi training integrates slow and intentional movements with breathing and cognitive skills [97]. Programmes are generally open to participants, and do not rely on formal referrals, for example from social prescribing operations (though informal recommendations may have been made). This tai chi is thus institutionally similar to many yoga or mindfulness programmes-open to all, but less likely to attract people with more severe therapeutic needs. The assessed tai chi MBI programme is delivered by Living Movement in Devon, and led by tai chi master Angus Clark [141]. There are many forms of tai chi and qigong: this programme is based on the short form developed by Cheng Man-ch'ing [142,143]. It has been estimated that $12 \%$ of the UK population engage in yoga each week, $7 \%$ in various forms of meditation and $21 \%$ in prayer daily [17,144].

\subsection{Assumptions}

We include analysis of four datasets $(n=642$ people): from Green Light Trust $(n=32)$, Trust Links Growing Together $(n=328)$, Ecominds green care interventions $(n=154)$, and a tai chi programme $(n=128)$. We present findings on the costs saved, and benchmark the life satisfaction/happiness benefits created with other life events and equivalent income values in the UK. Cohorts were evaluated for the GLT data (2019-2020), TL-Growing Together over the 2017-2020 period; Ecominds from 2013; tai chi over the 2016-2018 period. Data were gathered by staff of the NBI operations (trained by the University of Essex), and thus under local ethics rules and guidance.

A range of impact data were gathered for the four programmes. We focus here on the key question relating to life satisfaction/happiness adopted by the ONS in 2013, and on recorded data on the use of public health and other services by clients and participants. The positivity question has been widely benchmarked in national panel surveys $[145,146]$, and in national well-being and happiness comparisons $[17,21,22]$. Some evaluations of SP and NBI programmes have measured the impact on GP appointments and hospital admissions, and the costs saved have been calculated using a range of different methods $[65,87,140]$.

Here we make the following assumptions about the creation of a benefits register:

i. We use the guidance and methods set out by the government's Treasury Green Book [147] for benefits appraisal. The unit costs saved for public services are drawn from the New Economy Manchester cost-benefit analysis spreadsheets and unit costs database (v 2.0 updated April 2019), and draw upon costs in Pretty et al. [6]. We use best practice recommended in the Treasury Green Book by calculating cost savings over 1 and 10 years. We use a discount rate of 3.5\% (costs saved today are worth more than those in the future), and a standard $2 \%$ GDP deflator (to take account of inflation). This permits creation of a net present social value (NPSV) for interventions.

ii. We use the norm of "reliable improvement" as an outcome measure [56,67]. Evaluations of Improving Access to Psychological Therapies (IAPT) programmes show that $40-50 \%$ of individuals make complete recoveries, and some $63-67 \%$ make reliable improvements over the long term. This suggests that some $30 \%$ of individuals do not benefit from the designed interventions. We thus differentiate where data exist between participants who make "reliable improvements" to their well-being and those who receive no benefit.

iii. A number of biases may be inherent in these analyses [147]. There may be an optimism bias of observers and deliverers of programmes that unintentionally inflates beneficial outcomes. There may be an unmeasured counterfactual of natural recovery: some improvements to 
individuals would have occurred regardless of the intervention, as would some adverse outcomes. Displacement may also occur: where one benefit achieved may be at the cost to another service. Regional variations in economic costs of programmes and service delivery are not included, nor can account be taken of cultural norms of behaviours and habits that may vary across social classes and at different locations in the UK. We also do not make adjustments for gender differences in uptake of programmes (SP typically shows a gender bias in uptake of $60 \%$ women, $40 \%$ men) or of outcomes (NBI programmes have found no differences in outcomes according to gender). Finally, no specific adjustments have been made for the substantial social, economic and cultural changes occurring since the worldwide outbreak of the Covid-19 virus.

iv. Economic evaluations of SP and NBI programmes have often included in their benefits register the costs saved from reductions in benefits payments (on the assumption that individuals have returned to work), and the increase tax contributions from such employment. The evidence is also compelling that these types of programmes can result in measurable improvements to self-esteem and mood, improved sleep patterns, and changed habits that would lead to greater happy longevity. Here we focus on costs saved from three types of public services: health and social care, police and criminal justice, and education. We also analyse the marginal improvements in life satisfaction and happiness, and indicate the substantial changes required in society to achieve similar benefits. We conclude that economic benefits measured by these interventions are minima, as not all changes have been monetised.

\section{Results}

\subsection{Impacts on Changes to Life Satisfaction/Happiness}

There is a growing understanding of the science of happiness $[17,21,22,146]$. The UK government's Office for National Statistics (ONS) has been measuring well-being since 2013, and the World Happiness Reports measure annual changes in happiness across $>150$ countries and $>150$ cities. We have been able to assess the impacts on LS/H of the four NBI and MBI programmes. Figure 1 shows the marginal changes in LS/H, benchmarked against the UK average (7.69 for 2019), and the proportions of the UK population recording scores between 0 and $4.99(5 \%), 5.00$ and $6.99(15 \%), 7.00$ and $8.99(50 \%)$ and 9.00 and $10.00(30 \%)[17,148]$.

Table 1 and Figure 1 contain the mean changes in LS/H across all programmes $(+1.00 \mathrm{pts}$ on the 1-10 scale; $p<0.001)$. The woodland therapy of the Green Light Trust increased LS/H by +1.36 ; the ecotherapy/green care of Ecominds by +0.87 ; the therapeutic horticulture of Trust Links by +1.03 ; and the tai chi of Living Movement by +0.97 (all $p<0.001$ ). The published literature shows that it is generally hard and/or costly to make changes of $+1 \mathrm{pt}$ at the population level $[21,22,146]$. Existing levels are stubborn, and positive and negative changes as a result of significant life events are usually $<1.0$ (such marriage and birth of a child; divorce and loss of job: $[145,146]$. The What Matters Course run by Action for Happiness ( 8 weeks duration) trained 1500 people by mid-2019, and produces a $1 \mathrm{pt}$ average increase in LS/H after two months on the course [17].

We have segmented the subpopulations of non- and negative responders for the GLT $(23.1 \%$ of participants), Trust Links (10.6\%) and Ecominds (26.2\%). These are the participants who have not benefitted from the intervention or who have become worse. There were no non-responders in the tai chi sample. The proportion of non- or negative responders is lower than in SP and IAPT programmes (recorded as approximately $35 \%$ ). For those who responded positively to the NBIs, the marginal improvements in LS/H rose to +1.91 for the GLT, +1.60 for Trust Links, and +1.68 for Ecominds (all $p<0.001)$. The negative responders saw falls in $\mathrm{LS} / \mathrm{H}$ of between -1.00 and -2.32 .

We were able to segment the tai chi data according to prior length of practice using the $50 \mathrm{~h}$ habit benchmark to indicate novices $(0-50 \mathrm{~h})$, a 10-fold increase for experienced (50-500 h), and a further 10-fold increase for experts (500-5000+). The starting LS/H was highest for experts and lowest for novices; the marginal increases were highest for novices and experienced practitioners. The end point 
of 8.2 after intervention practice for experienced and expert was still below the top $30 \%$ of the national population (scoring 9-0). The Trust Links data also show a greater increase in LS/H for practitioners of horticulture over 2 years $(+1.27)$ than over $0-12$ months $(+1.02)$.

Table 1. Summary of impacts of NBIs and MBI on life satisfaction/happiness.

\begin{tabular}{|c|c|c|c|c|c|}
\hline NBI/MBI & Sample Size & $\begin{array}{c}\text { Start LS/H Score } \\
\text { (Mean } \pm \text { Standard } \\
\text { Deviation) }\end{array}$ & $\begin{array}{c}\text { End LS/H Score } \\
\text { (Mean } \pm \text { Standard } \\
\text { Deviation) }\end{array}$ & $\begin{array}{l}\text { Margin of } \\
\text { Change }\end{array}$ & $\begin{array}{c}\text { Significance } \\
\text { (Bonferroni-Adjusted } \\
t \text {-Test) }\end{array}$ \\
\hline \multicolumn{6}{|l|}{ All Participants } \\
\hline $\begin{array}{c}\text { Woodland Therapy: Green } \\
\text { Light Trust }\end{array}$ & 32 & $4.81 \pm 2.12$ & $6.17 \pm 1.64$ & +1.36 & $(p<0.01)$ \\
\hline Horticulture: Trust Links & 328 & $6.22 \pm 2.03$ & $7.25 \pm 1.93$ & +1.03 & $(p<0.001)$ \\
\hline Green Care: Ecominds & 154 & $6.10 \pm 2.33$ & $6.97 \pm 2.24$ & +0.87 & $(p<0.001)$ \\
\hline Tai Chi: Living Movement & 128 & $7.11 \pm 1.75$ & $8.08 \pm 1.51$ & +0.97 & $(p<0.01)$ \\
\hline Summary: All Interventions & 642 & $6.29 \pm 2.12$ & $7.29 \pm 1.99$ & +1.00 & $(p<0.001)$ \\
\hline \multicolumn{6}{|l|}{$\begin{array}{l}\text { Segmented: Responders } \\
\text { Only }\end{array}$} \\
\hline $\begin{array}{c}\text { Woodland Therapy: Green } \\
\text { Light Trust }\end{array}$ & 26 & $4.42 \pm 1.68$ & $6.33 \pm 1.25$ & +1.91 & $(p<0.001)$ \\
\hline Horticulture: Trust Links & 285 & $6.16 \pm 2.08$ & $7.76 \pm 1.66$ & +1.60 & $(p<0.001)$ \\
\hline Green Care: Ecominds & 122 & $5.78 \pm 2.27$ & $7.46 \pm 1.96$ & +1.68 & $(p<0.001)$ \\
\hline \multicolumn{6}{|l|}{$\begin{array}{l}\text { Segmented: Negative } \\
\text { Responders Only }\end{array}$} \\
\hline $\begin{array}{c}\text { Woodland Therapy: Green } \\
\text { Light Trust }\end{array}$ & 6 & $6.50 \pm 3.08$ & $5.50 \pm 2.86$ & -1.00 & $(p=0.28)$ \\
\hline Horticulture: Trust Links & 43 & $6.40 \pm 0.79$ & $5.05 \pm 1.30$ & -1.35 & $(p<0.001)$ \\
\hline Green Care: Ecominds & 32 & $7.38 \pm 2.11$ & $5.06 \pm 2.23$ & -2.32 & $(p<0.001)$ \\
\hline Impact over 2 years & & & & & Mixed ANOVA \\
\hline $\begin{array}{l}\text { Horticulture: Trust Links } \\
\qquad(0-12 \text { months })\end{array}$ & 166 & $6.13 \pm 1.92$ & $7.15 \pm 1.86$ & +1.02 & $(p<0.001)^{\mathrm{a}}$ \\
\hline $\begin{array}{l}\text { Horticulture: Trust Links } \\
\text { (12-24 months) }\end{array}$ & 60 & $6.13 \pm 1.92$ & $7.40 \pm 2.02$ & +1.27 & \\
\hline $\begin{array}{l}\text { Impact of Prior } \\
\text { Practice/Expertise }\end{array}$ & & & & & Mixed ANOVA \\
\hline $\begin{array}{c}\text { Tai Chi-Novice } \\
(0-49 \mathrm{~h})\end{array}$ & 53 & $6.79 \pm 1.85$ & $7.89 \pm 1.48$ & +1.10 & $(p=0.046)^{b}$ \\
\hline $\begin{array}{l}\text { Tai Chi-Experienced } \\
(50-499 \mathrm{~h})\end{array}$ & 42 & $7.10 \pm 1.57$ & $8.22 \pm 1.35$ & +1.12 & $(p<0.001)^{c}$ \\
\hline $\begin{array}{l}\text { Tai Chi-Expert } \\
(500-8000 \mathrm{~h})\end{array}$ & 33 & $7.62 \pm 1.76$ & $8.21 \pm 1.75$ & +0.59 & \\
\hline
\end{tabular}

a Significant main effect for time $(\mathrm{F}(1,418)=61.6, p<0.001)$, but no significant interaction or main effect for duration of practice. Post-hoc analyses confirm that scores significantly increase over time irrespective of duration of practice. ${ }^{b}$ Significant interaction effect $(\mathrm{F}(2,125)=3.1, p=0.046)$ and $\mathrm{a}^{\mathrm{c}}$ significant main effect for time $(\mathrm{F}(1,125)=101.8$, $p<0.001)$, but not group. Post-hoc analysis confirms that scores significantly increase over time for each of the three groups, but there is no statistically significant difference in these changes between the groups.

A further important factor is the LS/H characteristic of the populations of patients, participants or clients of the NBIs and MBIs. The UK mean score for LS/H (2019) was 7.69, with $20 \%$ of the population recording scores of $0.00-6.99$. A score in $\mathrm{LS} / \mathrm{H}$ of $<3.0$ is equated with misery. All four programmes started with mean levels of LS/H below the national average. The GLT population started at 4.81, indicating a referred population in the bottom $5 \%$ of the national population. Ecominds and Trust links started at $6.11-6.43$, in the bottom $20 \%$ of population. The tai chi self-referred population begins closest to the national average (6.79-7.62) and ends above the population average at 8.2 for experienced and expert practitioners. 


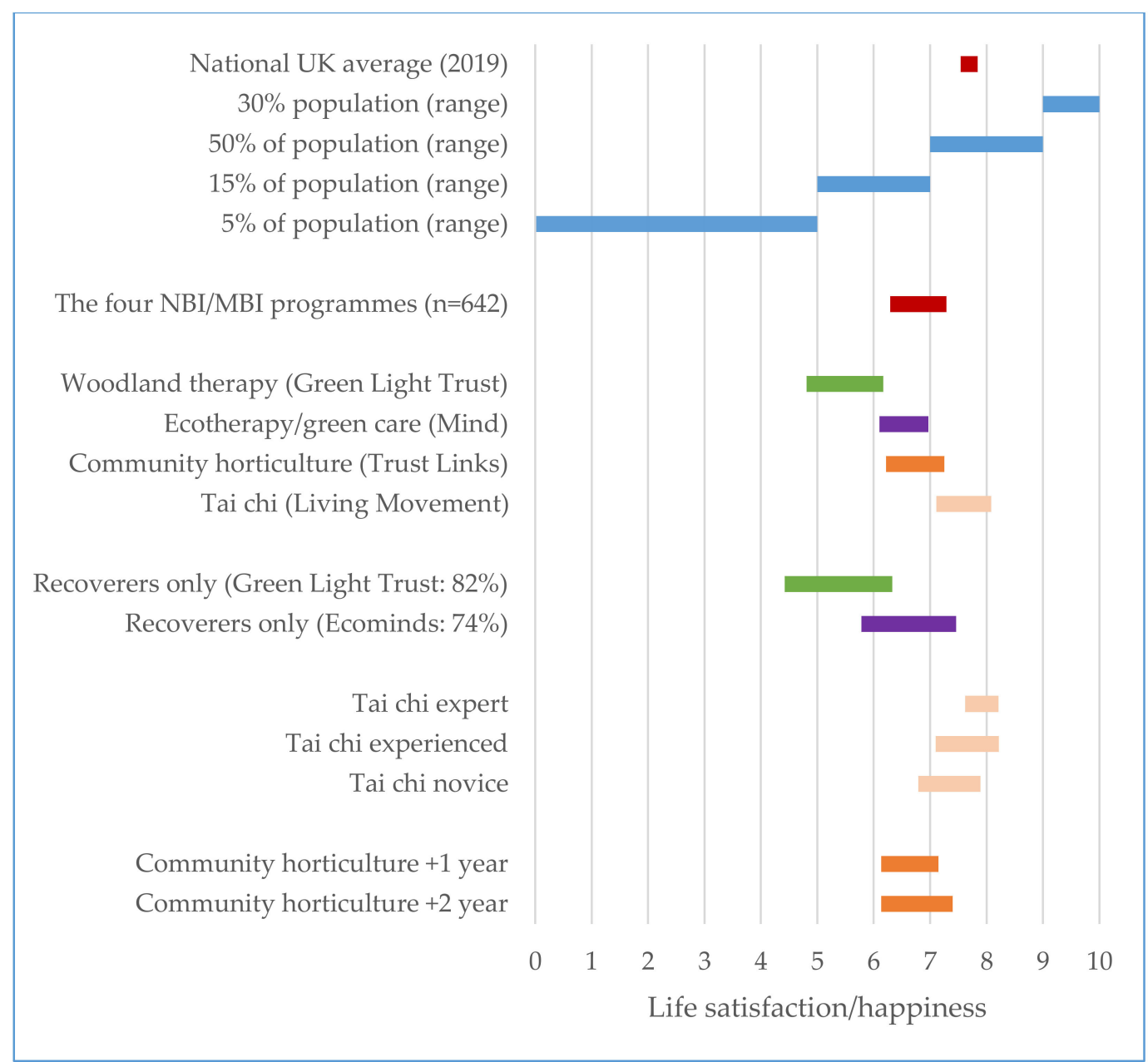

Figure 1. Margins of improvement of life satisfaction/happiness following four nature-based and mind and body interventions.

\subsection{Impacts on Costs Saved}

Benefits can be presented in two ways: (i) the ratio of social benefits to cost of delivery; and (ii) the net present value of the benefit created (cost saved), at 1 year and 10 year time periods [147]. No published analyses of SP, IAPT and NBIs-MBIs have used the 10 year point recommended by the UK Treasury Green Book, and there is no accepted standard evaluation point after intervention or course, though most are conducted at end of course or within a year of completion.

We calculate the economic benefits of NBI/MBI programmes using three measures: (a) reduced costs on public health and other services, (b) reduced health costs arising from reduced loneliness, and (c) economic benefits created from LS/H improvements in income equivalents. We do not have data on changes to employment status post-interventions, so do not calculate potential reductions in benefit claims and consequent increases in tax contribution to the public purse, as has been calculated elsewhere [140], nor do we have data on avoided prescription use/costs or prevented deployment of community nurses (e.g., psychiatric) [87].

(a) Some evaluations of social prescribing programmes have recorded outcomes on service use, again though over variable time periods after intervention. The ranges for improvements after one year are 15-25\% reductions in GP appointments, 20-25\% reductions in A\&E appointments, and $35-50 \%$ reductions in secondary treatments in hospitals [58]. We only have data on the use of public services from the GLT NBI (Table 2). These show changes in the use of GP appointments, A\&E visits to hospitals, and recorded engagements with police and criminal justice systems. 
Table 2. Changes in public health/service use (GLT cohorts) over 12 weeks.

\begin{tabular}{cccc}
\hline & $\begin{array}{c}\text { Changes in Number of GP Visits } \\
\text { (over 12 Weeks of Programme Compared } \\
\text { with Previous 12 Weeks) }\end{array}$ & $\begin{array}{c}\text { Changes in Number of } \\
\text { A\&E Hospital Visits }\end{array}$ & $\begin{array}{c}\text { Changes in Police } \\
\text { Incidents }\end{array}$ \\
\hline GLT-whole cohort & -2.50 & -0.44 & +0.03 \\
\hline GLT-responders only & -2.84 & -0.75 & -0.06 \\
\hline
\end{tabular}

Using the Treasury Green Book (2019) and Manchester New Economy (2019) data, the savings for the GLT NBI have been calculated at the year 1 and year 10 time points (Table 3).

Table 3. Per capita economic benefits created in NBI/MBI programmes from reduced use of public services, reduced loneliness and increased life satisfaction/happiness.

\begin{tabular}{|c|c|c|c|}
\hline Costs and Benefits & NBI/MBI & Benefits after Year 1 & Benefits after Year 10 \\
\hline $\begin{array}{l}\text { A: Costs prevented from reduced } \\
\text { public services use ( } n=32 \text { or } 26)\end{array}$ & $\begin{array}{l}\text { Green Light Trust } \\
\text { Full cohort } \\
\text { Responders only }\end{array}$ & $\begin{array}{c}£ 831 \\
£ 1521\end{array}$ & $\begin{array}{c}£ 6456 \\
£ 11,980\end{array}$ \\
\hline $\begin{array}{l}\text { B: Costs prevented from reduced } \\
\text { loneliness }(n=671)\end{array}$ & $\begin{array}{l}\text { Green Light Trust, } \\
\text { Ecominds, Trust Links, } \\
\text { Living Movement }\end{array}$ & $£ 714$ & $£ 5317$ \\
\hline \multirow{2}{*}{$\begin{array}{l}\text { C: Benefits created from increased } \\
\text { LS/H (income equivalent) per } \\
\text { individual }\end{array}$} & Green Light Trust & $£ 12,097$ & $£ 7271$ \\
\hline & Trust Links & $£ 6550$ & $£ 3963$ \\
\hline \multirow{8}{*}{$\begin{array}{l}\text { Total economic benefits per person } \\
(A+B+C)\end{array}$} & Ecominds & $£ 6550$ & $£ 3963$ \\
\hline & Living Movement & $£ 5430$ & $£ 3285$ \\
\hline & Green Light Trust & & \\
\hline & Full cohort & $£ 13,642$ & $£ 14,332$ \\
\hline & Responders only & $£ 14,332$ & $£ 24,568$ \\
\hline & Trust Links* & $£ 7264$ & $£ 9280$ \\
\hline & Ecominds* & $£ 7264$ & $£ 9280$ \\
\hline & Living Movement* & $£ 6144$ & $£ 8602$ \\
\hline
\end{tabular}

Note: Annual discount rates of $-3.5 \%$ and inflation of $-2 \%$ applied per year; $\mathrm{Y} 0=$ year of $\mathrm{NB}$ intervention; $\mathrm{Y} 1=$ end of first year; $\mathrm{Y} 10$ = end of ten years; NPSV = net present social value; years of cohort interventions and evaluation: 2016-2020. No data * on reduced GP/A\&E costs from Ecominds, Trust Links and Living Movement.

(b) We assume that the NBI programmes reduced loneliness and social isolation, as there are explicit aims to increase both nature and social connectedness. Loneliness increases annual GP visits by 1.8-fold and annual A\&E visits by 1.6-fold [8]. We assume that these are reduced to the levels found in the GLT cohort. This results in additional Y1 savings of $£ 714$ and Y10 NPSV (savings) of $£ 5317$ (Table 3).

(c) A third approach is to benchmark the changes in income that would be needed to achieve the equivalent improvements in LS/H observed in these NBI/MBI programmes [87,146,149]. Collins [150] has calculated that a $1 \mathrm{pt}$ increase in LS/H produces higher economic benefits to individuals starting at lower LS/H: for those on the median income of $£ 23 \mathrm{k}$, an increase of $1 \mathrm{pt}$ from 4 to 5 is equal to $+£ 13,100$ of income; for those on 5 to $6, £ 9230$ of income; for those on 6 to 7 , $£ 7140$ of income, and for those on 7 to $8, £ 5920$ of income. We assume that these benefits accrue only once, so are counted only in year 1 . Taking the mean LS/H increase of $+0.97 \mathrm{pt}$, after one year, the NBI of the Green Light Trust thus adds $£ 12,097$ of value to each individual; Ecominds and Trust Links add £6550, and the Living Movement tai chi $£ 5430$. The 10 year benefits are smaller, as both discount rates and inflation are added each year (Table 3).

A wide range of social benefit-cost ratios have been recorded in the literature for social prescribing and NBI programmes, again with no consistent time point for measurement. For SP programmes, benefit-cost ratios range from $£ 1.25$ to 1.50 for each $£ 1$ invested (at 1 year) and $£ 2.00$ for each $£ 1$ (at 5 years) [58]. For NBIs, such as care farms, green gyms, city farms, garden and horticulture projects, rates of return are typically 1.4:1 to 4.0:1, though some appear to rise to $6.9: 1$ to $10: 1[65,87]$. 
Table 4 summarises the costs of intervention and delivery in SP, IAPT and NBI programmes: these vary per individual from $£ 320$ to $£ 1400[61,68,82,146]$. This variation is partly explained by the length of designed intervention and specificities of content: for example, some programmes may appear to be low cost, but the hours of delivery might be too few to be effective in forming sustainable new habits and behaviours.

Table 4. Costs of delivery of NBI, SP and IAPT programmes.

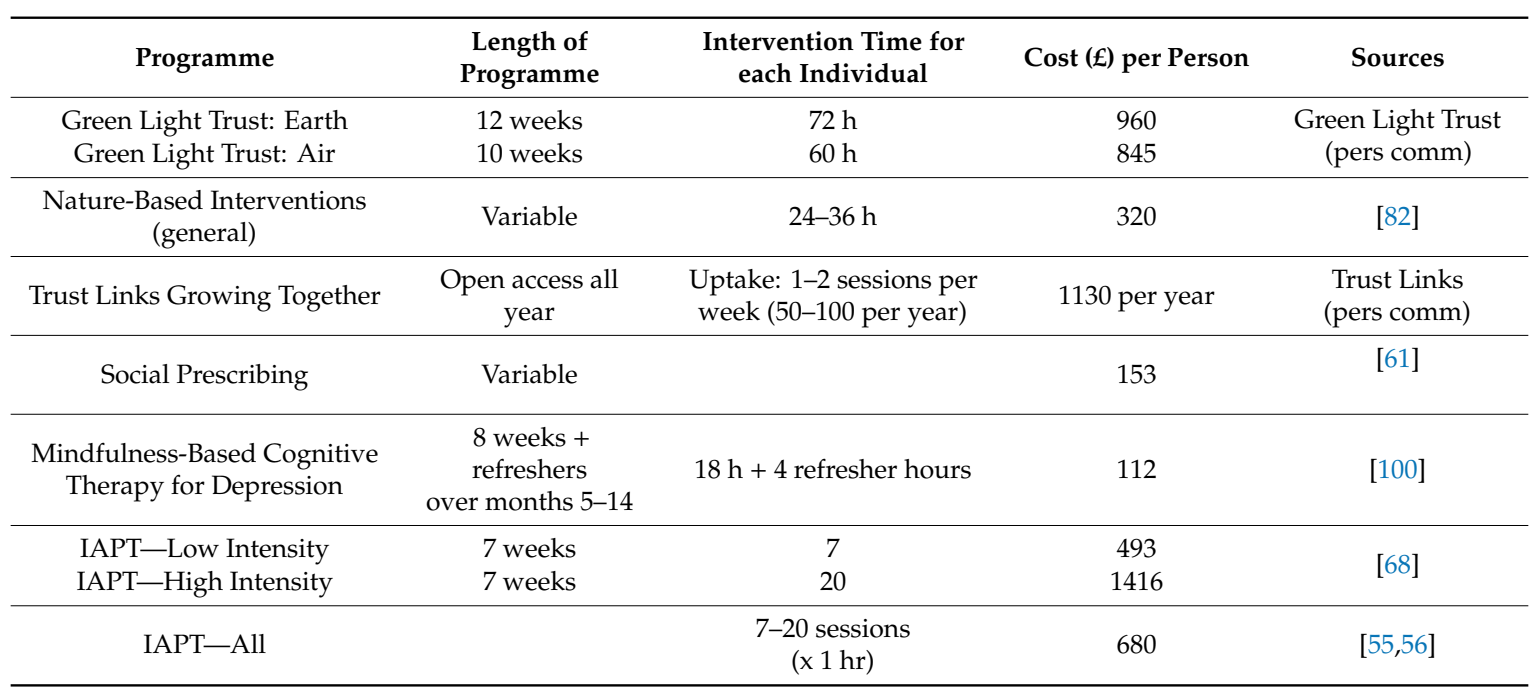

The ratios of benefits to cost of delivery for the Green Light Trust and Trust Links NBIs are shown in Table 5, and include the segmented returns for the subpopulation of GLT responders only. We do not have equivalent costs for Ecominds because of the wide variety of projects, nor for the Living Movement tai chi training and personal practice. The benefit-cost ratios at $\mathrm{Y} 1$ are $0.86-1.58$ and between 6.81 and 12.47 at Y10, indicating a payback period of 14 months (for full cohort) and 7.5 months (for responders only). These social returns on investments in the GLT NBIs are favourable compared with other NBI and SP programmes (typically 2.0-5.0 to 1.0), and highly beneficial when compared with no intervention.

Table 5. Ratio of public benefits-private costs of delivery.

\begin{tabular}{ccc}
\hline & End Y1 & End Y10 \\
\hline Green Light Trust (prevented public health and services costs only) & & 12.9 \\
Full cohort & 1.71 & 19.1 \\
Responders only & 2.47 & 15.8 \\
Green Light Trust (total benefits) & 15.1 & 27.1 \\
Full cohort & 15.8 & 7.61 \\
\hline Responders only & 6.42 & \\
\hline
\end{tabular}

Note: Cost of the GLT NBI = £960 per person per programme (2020); Trust Links $£ 1130$ per person per year.

\section{Discussion}

The literature on life satisfaction and happiness makes a very clear observation: it is difficult to achieve movements of $+1 \mathrm{pt}$ on the 1-10 pt scale. In the World Happiness Reports [21,22], the maximum change across whole populations in life satisfaction/happiness (LS/H) over a decade (2005-2006 to 2016-2018) is 1.0-1.3 (5 countries), then 0.5-1.0 (30 countries) and 0-0.5 (43 countries). From 2008-2012 to $2017-2019,10$ countries $>1.0,31$ between 0.5 and 1.0 , and 34 countries $0-0.5$. Over a decade, only $5-10$ 
countries and no cities see increases of $>1.0 \mathrm{pt}$ (Table 6). In summary, it is hard to move even one point on the LS/H scale. It is clear that against these changes, the NBI/MBI programmes achieve important changes in LS/H for responding participants. As shown in Table 1, a proportion of participants are non- or negative responders (11-26\%): this may be because the intervention does not suit them or is ineffective, or because external negative life events have intervened during the course.

Table 6. Number of countries and cities showing positive movements in life satisfaction/happiness over approximate 10 year periods.

\begin{tabular}{cccc}
\hline $\begin{array}{c}\text { Changes in Life Satisfaction/Happiness (LS/H) } \\
\text { across Whole Populations }\end{array}$ & \multicolumn{2}{c}{ Number of Countries } & Number of Cities \\
\hline & 2005-2006 to 2016-2018 & 2008-2012 to 2017-2019 & 2005 to 2013 \\
\hline Increases $>1.0$ & 5 & 10 & 0 \\
$0.5-0.99$ & 30 & 31 & 22 \\
$0.0-0.49$ & 43 & 34 & 66 \\
Falls by -0.01 to -1.5 & 50 & 71 & 81 \\
\hline
\end{tabular}

Source: WHR [21,22].

A second approach to benchmarking the marginal changes in LS/H observed in the NBI/MBI programmes is to compare with the changes that result from significant life events (Table 7). Clark et al. $[145,146]$ have measured the effect on LS/H of key life events, both positive (e.g., new partnership or marriage) and negative (e.g., loss of job). They find that LS/H may rise or fall before an event (in anticipation) and/or persist afterwards (with personal scarring if negative). All the effects of positive life events are less than 1.0; the effects of negative events can be to reduce LS/H scores by -0.4 to -1.3 . Once again, it is clear that against the changes provoked by life events, the NBI/MBI programmes achieve important changes in life satisfaction and happiness for participants that could add to other changes and/or offset the effects of negative events and stressors.

Table 7. Effect of life events on life satisfaction/happiness scores (data from household panel surveys: UK, Germany, and Australia).

\begin{tabular}{cccc}
\hline Significant Life Event & Women/Men & $\begin{array}{c}\text { Effect on LS/Happiness } \\
\text { (on 1-10 Scale) }\end{array}$ & $\begin{array}{c}\text { Changes in 5 Years after } \\
\text { the Life Event }\end{array}$ \\
\hline \multirow{2}{*}{ Partnership } & Women & $\begin{array}{c}+0.5 \text { to }+0.7 \\
+0.4 \text { to }+0.5\end{array}$ & Stable \\
& Men & +0.4 & Stable \\
Parenthood & Women & +0.2 & Then rising by +0.5 after \\
& Men & -0.5 to -1.0 & years \\
\hline \multirow{2}{*}{ Separation/Divorce } & Women & -1.0 to -1.3 & Then returning \\
& Men & -0.6 to -1.0 & completely after 1 year \\
\hline \multirow{2}{*}{ Widowhood } & Women & -0.5 to -1.0 & Then falling to -1.2 after \\
& Men & -0.4 & 5 years \\
\hline \multirow{2}{*}{ Loss of Employment } & Women & -0.4 &
\end{tabular}

A third consideration is the effect on equity. We indicated that the client cohorts on the four NBI/MBI programmes started with mean LS/H scores below the UK population mean (7.69). It has been noted in the literature that a $1 \mathrm{pt}$ increase for those starting low is worth more (to the individuals and for society as a whole as it decreases inequity) than a 1 pt increase from a higher start (e.g., 8 or 9) $[17,146]$. The GLT client population starts lowest, in the lowest $5 \%$ of population, yet shows the largest increases of +1.36 to +1.82 . Those for Ecominds and Growing Together started higher at 5-6 (in the bottom 20\% of the population), and achieve increases of +0.87 to +1.03 . The tai chi population started closer to the national average, and achieved changes of +0.97 . Some of the tai chi practitioners can be assumed to have benefitted from long-term engagement with the practice, and all were self-referred, having made lifestyle choices to engage with the practice. 
The natural and social interventions detailed here are thus deliberate interventions helping to reduce health inequalities $[24,25,151]$. They tend to be targeted more at people with low absolute health and well-being indicators (below the population average) and demonstrate that improvements can be made for individuals that result in reduced social inequality. This benefits all of society, as greater equality results in greater LS/H for all [17,22]. The World Happiness Reports [21,22] make clear that the structures of social-ecological-economic environments are a strong influence on happiness [22], and national surveys (e.g., DCMS [144]) on volunteering and social networks show the importance of social context in shaping LS/H and well-being. The World Happiness Reports [21,22] make clear that the greatest explanatory factors of differences in LS/H across countries and changes over years is prosociality, freedom to make choices, healthy life expectancy at birth, generosity of others, and low inequality. The effects of corruption and perceived dystopia are strong factors in reducing $\mathrm{LS} / \mathrm{H}$. As shown above, we have observed a mean increase as a result of the four NBIs/MBIs of +1.00 from the interventions $(n=642, p<0.001)$, rising to +1.88 for the segmented population of GLT responders.

We draw attention to some limitations to this research that will point toward new directions for research on the impacts of NBIs and MBIs. The results point toward rational policy responses, but as yet no preventative policies have been adopted at a scale that can be evaluated. We have not taken account of the potential effects of differing levels of biodiversity and landscape quality type utilized by the three NBIs and one MBI. We have only evaluated one MBI (tai chi) here: there are a range of types of tai chi and qi gong practiced, and these may produce differing outcomes. Evidence of other MBIs, such as yoga, pilates and prayer, would increase the range of knowledge on cost-effective interventions. Finally, these four NBIs/MBIs combine a range of components, including physical activity, cognitive engagement, presence of nature, social connections and togetherness, and healthy food preparation and consumption. We are unable to say whether these are interacting with each other or independently contributing to happiness and life satisfaction.

However, a wide range of evidence does now show that a package of six life-course or lifestyle components increases the probability of healthy, happy and long lives. These comprise (i) access to and use of natural places and green space, (ii) regular physical activity (especially in green spaces: green exercise), (iii) healthy and mixed diets, (iv) being part of and embedded in rich social networks, (v) maintaining cognitive capability across the life course, and (vi) a life lived with a spiritual or meaning framework $[17,42,50,152,153]$.

\section{Conclusions}

We have shown that the package of four NBIs and MBIs was effective at raising LS/H of patients and participants. The increases of $1 \mathrm{pt}$ and above are hard to achieve at country and city levels (though sample sizes here are smaller), and here we find that the client population all start at LS/H below the UK population average, particularly for the three NBIs, showing that the less well and happy are able to benefit.

The economic returns have been calculated from both avoided costs on public health and other services, and from the equivalent income increases required to raise life satisfaction/happiness. The total economic returns to NBIs/MBIs are $£ 6000-£ 14,000$ per person after $Y 1$, and $£ 8600-£ 24,500$ per person after Y10. The economic returns for prevented costs only (not counting effects on LS/H) are $£ 800-£ 1500$ at $Y 1$, and $£ 5300-£ 12,300$ at $Y 10$. A single cohort of 10 responders for the GLT would thus produce $£ 22,350$ of savings for public services in one year, and $£ 173,000$ of savings after 10 years.

For the GLT woodland therapy, the ratios of public benefit-private cost of delivery are 1.71-2.47 after $Y 1$ (for costs prevented only), and rise to 15.1-15.8 when effects on life satisfaction/happiness are included. The ratios after Y10 rise to 12.9-27.1:1. For the Trust Links community horticulture, the total benefits to costs are 6.42 for $\mathrm{Y} 1$ and 7.61 for $\mathrm{Y} 10$. It is thus clear that NBIs can contribute to the "prevention pays" policy of the NHS and the government $[8,10]$, along with the growing expansion of support for social prescribing and psychological therapies $[56,58]$. 
Some form of screening clearly occurs before the therapeutic programmes of intervention, with referring organisations making assumptions about who might benefit. We note that the proportion of non- or negative responders is smaller (10-26\%) than those recorded in social prescribing and IAPT programmes (approx. $35 \%$ ), but we cannot conclude that these programmes could be beneficial for all. Some participants may be affected by external events during a course, and thus show negative responses independent of the effect of the NBI.

We are also unable to say whether these NBIs and MBIs will result in adherence over a long period of time. However, programmes with at least $50 \mathrm{~h}$ of practice do have a greater chance of forming automated habits and behaviours capable of delivering long-term health benefits. The Ecominds green care projects were variable in length, but the Green Light Trust and Trust Links programmes are designed to have participants exceed the $50 \mathrm{~h}$ habit-forming norm, and the data from the Living Movement tai chi practitioners show that two-thirds were experienced or experts ( $>50 \mathrm{~h}$ practice). Some segments of data indicate a changing dose-response relationship over time, with both community horticulturalists and tai chi practitioners showing higher $\mathrm{LS} / \mathrm{H}$ with increasing practice over several years.

These data suggest public policy at local and national levels should encourage investments in NBIs and MBIs, as programmes at scale will deliver substantial benefits and contribute to the aspirations of the CMO [8] to prevent cost pressures on the health and social care sectors. The government's 25 Year Environment Plan [79] sets out the importance of natural habitats and green space for health, and further points to the contribution social prescribing can make to national health and well-being.

However, targets for participation have not yet been set by either health or environment ministries. New Zealand issued an explicit well-being budget in 2019, and Sweden has set a Vision Zero target for road traffic accidents, accepting that there will be individual errors, but that the national target should be zero deaths [8]. In the UK, a soft drinks levy was introduced in April 2018 [9], and was expected to remove $45 \mathrm{M} \mathrm{kg}$ of sugar per year from soft drinks. No country, though, has as yet set similarly ambitious targets for non-communicable diseases (NCDs): for example, returning levels of adult obesity to 1990 levels (from 30\% to 3\%), reducing diabetes and loneliness incidence (by 10-fold), reducing mental ill health from $16 \%$ of the adult population in any one year to $1.6 \%$ (10-fold reduction), or increasing fruit and vegetable consumption from 3.5 to 5 portions per day (and thus for $20 \%$ of the population, from zero to 5 ).

The Marmot Review [151] of health inequalities concluded that "economic growth is not the most important measure of our country's success," and prioritised the accumulation of the positive effects on well-being across the whole life course by building social capital, encouraging active travel, use of public transport, availability of green space and healthy eating, and promotion of nature-based interventions for health. We conclude that greater adoption of formal and informal NBIs and MBIs would increase national well-being and reduce inequalities of health. A number of effective training programmes are also available to increase happiness [17].

A greener economy that emphasises ecological public health [6,154-157] would be one in which attention is paid to the environmental and social context of the public not yet ill, and all patients and professionals engaged in treatment and care $[8,10]$. It might also address the most pressing global challenge of climate change driven by material consumption patterns, where world greenhouse gas $\left(\mathrm{CO}_{2}\right.$ equivalent) emissions need to be reduced from 53 to $10 \mathrm{Gt}$ annually to create a safe place for humanity $[15,158,159]$. This will require new habits and behaviours to be taken up by whole populations, particularly those that encourage non-material consumption over material goods, and then adherence over sustained periods $[16,160,161]$.

The Department for Health and Social Care [9] observed that "prevention and early intervention programmes represent very good value for money" in that poor health and well-being can be improved while at the same time taking cost and pressure away from primary and secondary health and public service systems. There are high levels of satisfaction with social and green prescribing $[63,66]$, but it also important that these programmes do not become a reason for cutting public services. We conclude that nature-based and mind-body interventions can play an important role in helping to achieve these 
aspirations, particularly in a post-Covid-19 world, where economic and social stresses on individuals and health systems will be higher.

Author Contributions: Both authors (J.P. and J.B.) were equally involved in all aspects of research for this paper: conceptualization, formal analysis, investigation, and writing (draft preparation, review and editing). Both authors have read and agreed to the published version of the manuscript.

Funding: This research received no external funding.

Acknowledgments: The analysis and conclusions in this paper were developed independently of the four NBI/MBI programmes.

Conflicts of Interest: The authors declare no conflict of interest.

\section{References}

1. Friedman, H.S.; Martin, L.R. The Longevity Project; Hay House: London, UK, 2011.

2. Gratton, L.; Scott, A. The 100 Year Life; Bloomsbury: London, UK, 2018.

3. WHO. A Healthy Diet Sustainably Produced; WHO/NMH/NHD 18.18 Technical Report; WHO: Copenhagen, Denmark, 2018.

4. Foresight. Mental Health—Future Challenge; Government Office of Science: London, UK, 2008.

5. Royal Society. People and the Planet; Royal Society: London, UK, 2012.

6. Pretty, J.; Barton, J.; Bharucha, Z.P.; Bragg, R.; Wood, C.; Pencheon, D. Improving health and well-being independently of GDP: Dividends of greener and prosocial economies. Int. J. Environ. Health Res. 2015, 11, 1-26. [CrossRef] [PubMed]

7. Lancet. Planetary health: From concept to decisive action. Lancet 2019, 3, e402.

8. CMO (Chief Medical Officer). Annual Report 2018: Better Health Within Reach; UK Government: London, UK, 2018.

9. DHSC. Prevention Is Better than Cure; Department of Health and Social Care: London, UK, 2018.

10. CMO (Chief Medical Officer). Chief Medical Officer's Annual Report 2012: Our Children Deserve Better: Prevention Pays; UK Government: London, UK, 2013.

11. AMS (Academy of Medical Sciences). Health of the Public in 2040; AMS: London, UK, 2018; Available online: https://acmedsci.ac.uk/policy/policy-projects/health-of-the-public-in-2040 (accessed on 1 July 2020).

12. NHS. Social Prescribing. 2019. Available online: https://www.england.nhs.uk/personalisedcare/socialprescribing/ (accessed on 1 July 2020).

13. Pretty, J.; Barton, J.; Rogerson, M. Green Mind Theory: How brain-body-behaviour links into natural and social environments for healthy habits. Int. J. Environ. Res. Public Health 2017, 14, 706. [CrossRef] [PubMed]

14. Jackson, T. Prosperity without Growth; Earthscan: London, UK, 2009.

15. Pretty, J. The consumption of a finite planet: Well-being, convergence, divergence, and the nascent green economy. Environ. Resour. Econ. 2013, 55, 475-499. [CrossRef]

16. Dorling, D. Slowdown; Yale University Press: New Haven, CT, USA, 2020.

17. Layard, R. Can We Be Happier? Pelican: London, UK, 2020.

18. Easterlin, R.A. Does economic growth improve the human lot? Some empirical evidence. In Nations and Households in Economic Growth; Academic Press: Cambridge, MA, USA, 1974; pp. 89-125.

19. Diener, E. Subjective well-being. The science of happiness and a proposal for a national index. Am. Psychol. 2000, 55, 34-43. [CrossRef] [PubMed]

20. Raworth, K. Doughnut Economics: Seven Ways to Think like a 21st-Century Economist; Chelsea Green Publishing: White River Junction, VT, USA, 2017.

21. Helliwell, J.F.; Layard, R.; Sachs, J.D. (Eds.) World Happiness Report 2019; Sustainable Development Solutions Network: New York, NY, USA, 2019.

22. Helliwell, J.F.; Layard, R.; Sachs, J.D.; De Neve, J.-E. (Eds.) World Happiness Report 2020; Sustainable Development Solutions Network: New York, NY, USA, 2020.

23. Kasser, T. The High Price of Materialism; MIT Press: Cambridge, MA, USA, 2002.

24. Wilkinson, R.; Pickett, K. The Spirit Level; Penguin: London, UK; New York, NY, USA, 2009.

25. Wilkinson, R.; Pickett, K. The Inner Level; Allen Lane: London, UK, 2016.

26. Piketty, T.; Saez, E. Inequality in the long run. Science 2014, 344, 838-843. [CrossRef] 
27. Mitchell, R.; Popham, F. Effect of exposure to natural environment on health inequalities: An observational population study. Lancet 2008, 372, 1655-1660. [CrossRef]

28. Mitchell, R.J.; Richardson, E.A.; Shortt, N.K.; Pearce, J.R. Neighborhood environments and socioeconomic inequalities in mental well-being. Am. J. Prev. Med. 2015, 49, 80-84. [CrossRef]

29. Kim, S.H.; Kim, M.S.; Lee, M.S.; Park, Y.S.; Lee, H.J.; Kang, S.A.; Lee, H.S.; Lee, K.E.; Yang, H.J.; Kim, M.J.; et al. Korean diet: Characteristics and historical background. J. Ethn. Foods 2016, 3, 26-31. [CrossRef]

30. Cacioppo, J.T.; Hawkley, L.C.; Berntson, G.G. The anatomy of loneliness. Curr. Dir. Psychol. Sci. 2003, 12, 71-74. [CrossRef]

31. Hawkley, L.C.; Cacioppo, J.T. Aging and loneliness. Downhill quickly? Curr. Dir. Psychol. Sci. 2007, 16, 187-191. [CrossRef]

32. Holt-Lunstad, J.; Smith, T.B.; Layton, J.B. Social relationships and mortality risk: A meta-analytic review. PLoS Med. 2010, 7, e1000316. [CrossRef] [PubMed]

33. Holt-Lunstad, J.; Smith, T.B.; Baker, M.; Harris, T.; Stephenson, D. Loneliness and social isolation as risk factors for mortality: A meta-analytic review. Perspect. Psychol. Sci. 2015, 10, 227-237. [CrossRef] [PubMed]

34. Holt-Lunstad, J.; Robles, T.F.; Sbarra, D.A. Advancing social connection as a public health priority in the United States. Am. Psychol. 2017, 72, 517. [CrossRef]

35. Borgonovi, F. Doing well by doing good. The relationship between formal volunteering and self-reported health and happiness. Soc. Sci. Med. 2008, 66, 2321-2334. [CrossRef]

36. Borgonovi, F. A life-cycle approach to the analysis of the relationship between social capital and health in Britain. Soc. Sci. Med. 2010, 71, 1927-1934. [CrossRef]

37. Anderson, N.D.; Damianakis, T.; Kröger, E.; Wagner, L.M.; Dawson, D.R.; Binns, M.A.; Bernstein, S.; Caspi, E.; Cook, S.L. The benefits associated with volunteering among seniors: A critical review and recommendations for future research. Psychol. Bull. 2014, 140, 1505. [CrossRef]

38. Rojas-Rueda, D.; Nieuwenhuijsen, M.J.; Gascon, M.; Perez-Leon, D.; Mudu, P. Green spaces and mortality: A systematic review and meta-analysis of cohort studies. Lancet Planet. Health 2019, 3, e469-e477. [CrossRef]

39. Ward Thompson, C.; Silveirinha de Oliveira, E.; Tilley, S.; Elizalde, A.; Botha, W.; Briggs, A.; Cummins, S.; Leyland, A.H.; Roe, J.J.; Aspinall, P.; et al. Health impacts of environmental and social interventions designed to increase deprived communities' access to urban woodlands: A mixed-methods study. Public Health Res. 2019, 7, 1-172. [CrossRef]

40. Rogerson, M.; Brown, D.; Sandercock, G.; Wooler, J.; Barton, J. A comparison of four typical green exercise environments and prediction of psychological health outcomes. Perspect. Public Health 2015. [CrossRef]

41. Micha, R.; Peñalvo, J.L.; Cudhea, F.; Imamura, F.; Rehm, C.D.; Mozaffarian, D. Association between dietary factors and mortality from heart disease, stroke, and type 2 diabetes in the United States. JAMA 2017, 317, 912-924. [CrossRef] [PubMed]

42. Ji, J.S.; Zhu, A.; Bai, C.; Wu, C.D.; Yan, L.; Tang, S.; Zeng, Y.; James, P. Residential greenness and mortality in oldest-old women and men in China: A longitudinal cohort study. Lancet Planet. Health 2019, 3, e17-e25. [CrossRef]

43. Marseglia, A.; Wang, H.X.; Rizzuto, D.; Fratiglioni, L.; Xu, W. Participating in mental, social, and physical leisure activities and having a rich social network reduce the incidence of diabetes-related dementia in a cohort of Swedish older adults. Diabetes Care 2019, 2, 232-239. [CrossRef] [PubMed]

44. Lee, I.-M.; Paffenbarger, R.S. Associations of light, moderate, and vigorous intensity physical activity with longevity the harvard alumni health study. Am. J. Epidemiol. 2000, 151, 293-299. [CrossRef] [PubMed]

45. Willcox, D.C.; Scapagnini, G.; Willcox, B.J. Healthy aging diets other than the Mediterranean: A focus on the Okinawan diet. Mech. Ageing Dev. 2014, 136, 148-162. [CrossRef]

46. Steptoe, A.; Wardle, J. Enjoying life and living longer. Arch. Intern. Med. 2012, 172, 273-275. [CrossRef] [PubMed]

47. Danner, D.D.; Snowdon, D.A.; Friesen, W.V. Positive emotions in early life and longevity: Findings from the nun study. J. Personal. Soc. Psychol. 2001, 80, 804-813. [CrossRef]

48. Elwood, P.; Galante, J.; Pickering, J.; Palmer, S.; Bayer, A.; Ben-Shlomo, Y.; Longley, M.; Gallagher, J. Healthy lifestyles reduce the incidence of chronic diseases and dementia: Evidence from the Caerphilly Cohort Study. PLoS ONE 2013, 8, e81877. [CrossRef]

49. Vaillant G, E. Aging Well; Little, Brown and Co.: Boston, MA, USA, 2002. 
50. Lee, H.S.; Duffey, K.J.; Popkin, B.M. South Korea's entry to the global food economy: Shifts in consumption of food between 1998 and 2009. Asia Pac. J. Clin. Nutr. 2012, 21, 618.

51. Levitin, D. The Changing Mind: A Neuroscientist's Guide to Ageing Well; Penguin: London, UK, 2020.

52. Bratman, G.N.; Hamilton, J.P.; Daily G, C. The impacts of nature experience on human cognitive function and mental health. Ann. N. Y. Acad. Sci. 2012, 1249, 118-136. [CrossRef]

53. Bratman, G.N.; Anderson, C.B.; Berman, M.G.; Cochran, B.; De Vries, S.; Flanders, J.; Folke, C.; Frumkin, H.; Gross, J.J.; Hartig, T.; et al. Nature and mental health: An ecosystem service perspective. Sci. Adv. 2019, 5, eaax0903. [CrossRef] [PubMed]

54. O’Brien, L.; Ambrose-Oji, B.; Waite, S.; Aronsson, J.; Clark, M. Learning on the move: Green exercise for children and young people. In Green Exercise: Linking Nature, Health and Well-Being; Barton, J., Bragg, R., Wood, C., Pretty, J., Eds.; Routledge: Abingdon, UK, 2016.

55. Clark, D.M. Realizing the mass public benefit of evidence-based psychological therapies: The IAPT program. Annu. Rev. Clin. Psychol. 2018, 14, 159-183. [CrossRef] [PubMed]

56. IAPT. Psychological Therapies: Annual Report on the Use of IAPT Services 2018-19; NHS: London, UK, 2019.

57. Chatterjee, H.J.; Camic, P.M.; Lockyer, B.; Thomson, L.J. Non-clinical community interventions: A systematised review of social prescribing schemes. Arts Health 2018, 10, 97-123. [CrossRef]

58. NASP. National Academy for Social Prescribing 2020-2023 Strategic Plan; NASP: London, UK, 2019.

59. Dayson, C.; Bashir, N.; Bennett, E.; Sanderson, E. The Rotherham Social Prescribing Service for People with Long-Term Health Conditions; Annual Evaluation Report; The Centre for Regional Economic and Social Research, Sheffield Hallam University: Sheffield, UK, 2016.

60. Polley, M.J.; Pilkington, K. A Review of the Evidence Assessing Impact of Social Prescribing on Healthcare Demand and Cost Implications; University of Westminster: London, UK, 2017.

61. Bickerdike, L.; Booth, A.; Wilson, P.M.; Farley, K.; Wright, K. Social prescribing: Less rhetoric and more reality. A systematic review of the evidence. BMJ Open 2017, 7. [CrossRef]

62. Laing, K.; Steer, M.; Lawson, S.; Penn, L.; O’Brien, N.; Wildman, J. "It Was the Turning Point in My Life" How Ways to Wellness Social Prescribing Is Improving the Health and Wellbeing of People with Long Term Conditions; Newcastle University: Newcastle, UK, 2017.

63. Alderwick, H.A.; Gottlieb, L.M.; Fichtenberg, C.M.; Adler, N.E. Social prescribing in the US and England: Emerging interventions to address patients' social needs. Am. J. Prev. Med. 2018, 54, 715-718. [CrossRef]

64. Bromley by Bow Centre. Annual Review 2018; Bromley by Bow: London, UK, 2018.

65. Bragg, R.; Leck, C. Good Practice in Social Prescribing for Mental Health: The Role of Nature-Based Interventions; Natural England Commissioned Reports, Number 228; Natural England: York, UK, 2017.

66. Robinson, J.M.; Jorgensen, A.; Cameron, R.; Brindley, P. Let Nature Be Thy Medicine: A Socioecological Exploration of Green Prescribing in the UK. Int. J. Environ. Res. Public Health 2020, 17, 3460. [CrossRef]

67. Gyani, A.; Shafran, R.; Layard, R.; Clark, D.M. Enhancing recovery rates: Lessons from year one of IAPT. Behav. Res. Ther. 2013, 51, 597-606. [CrossRef]

68. Radhakrishnan, M.; Hammond, G.; Jones, P.B.; Watson, A.; McMillan-Shields, F.; Lafortune, L. Cost of Improving Access to Psychological Therapies (IAPT) programme: An analysis of cost of session, treatment and recovery in selected Primary Care Trusts in the East of England region. Behav. Res. Ther. 2013, 51, 37-45. [CrossRef]

69. Pigott, H.E.; Leventhal, A.M.; Alter, G.S.; Boren, J.J. Efficacy and effectiveness of antidepressants: Current status of research. Psychother. Psychosom. 2010, 79, 267-279. [CrossRef]

70. McCormack, J.; Korownyk, C. Effectiveness of antidepressants. BMJ 2018, 360, k1073. [CrossRef]

71. Pretty, J.; Peacock, J.; Sellens, M.; Griffin, M. The mental and physical health outcomes of green exercise. Int. J. Environ. Health Res. 2005, 15, 319-337. [CrossRef] [PubMed]

72. Barton, J.; Bragg, R.; Wood, C.; Pretty, J. Green Exercise: Linking Nature, Health and Well-Being; Routledge: Oxon, UK, 2017.

73. Barton, J.; Hine, R.E.; Pretty, J. The health benefits of walking in greenspaces of high natural and heritage value. J. Integr. Environ. Sci. 2009, 6, 261-278. [CrossRef]

74. Barton, J.; Pretty, J. What is the best dose of nature and green exercise for mental health? A meta-study analysis. Environ. Sci. Technol. 2010, 44, 3947-3955. [CrossRef] [PubMed]

75. Shanahan, D.F.; Bush, R.; Gaston, K.J.; Lin, B.B.; Dean, J.; Barber, E.; Fuller, R.A. Health benefits from nature experiences depend on dose. Sci. Rep. 2016, 6, 28551. [CrossRef] 
76. Rogerson, M.; Wood, C.; Pretty, J.; Schoenmakers, P.; Bloomfield, D.; Barton, J. Regular doses of nature: The efficacy of green exercise interventions for mental well-being. Int. J. Environ. Res. Public Health 2020, 17, 1526. [CrossRef]

77. NEA. National Ecosystem Assessment; Defra: London, UK, 2011.

78. Kubiszewski, I.; Costanza, R.; Anderson, S.; Sutton, P. The future value of ecosystem services: Global scenarios and national implications. Ecosyst. Serv. 2017, 26, 289-301. [CrossRef]

79. Defra. The 25 Year Environment Plan; Department for Environment, Food and Rural Affairs: London, UK, 2019.

80. Natural England. An Estimate of the Value and Cost Effectiveness of the Expanded Walking the Way to Health Initiative Scheme 2009 (TIN055); Natural England: London, UK, 2009.

81. Hamann, G.A.; Ivtzan, I. 30 minutes in nature a day can increase mood, well-being, meaning in life and mindfulness: Effects of a pilot programme. Soc. Inq. Well-Being 2016, 2, 34-46.

82. Bloomfield, D. What makes nature-based interventions for mental health successful? BJPsych Int. 2017, 14, 82-85. [CrossRef]

83. Wolsko, C.; Lindberg, K.; Reese, R. Nature-based physical recreation leads to psychological well-being: Evidence from five studies. Ecopsychology 2019, 11, 222-235. [CrossRef]

84. Cooley, S.J.; Jones, C.R.; Kurtz, A.; Robertson, N. 'Into the Wild': A meta-synthesis of talking therapy in natural outdoor spaces. Clin. Psychol. Rev. 2020, 77, 101841. [CrossRef]

85. Hubbard, G.; Thompson, C.W.; Locke, R.; Jenkins, D.; Munoz, S.A.; Van Woerden, H.; Maxwell, M.; Yang, Y.; Gorely, T. Co-production of "nature walks for wellbeing" public health intervention for people with severe mental illness: Use of theory and practical know-how. BMC Public Health 2020, 20, 1-12. [CrossRef]

86. Fields in Trust. Revaluing Parks and Green Space. 2019. Available online: http://www.fieldsintrust.org/ revaluing (accessed on 1 July 2020).

87. Wildlife Trusts. Social Return on Investment Analysis of the Health and Wellbeing Impacts of Wildlife Trust Programmes; Wildlife Trusts: Newark-on-Trent, UK, 2019; Available online: https:/www.wildlifetrusts.org/ news/new-report-reveals-prescribing-nature (accessed on 1 July 2020).

88. Forest School Association. Available online: https://www.forestschoolassociation.org/what-is-forest-school/ (accessed on 1 July 2020).

89. Barton, J.; Bragg, R.; Pretty, J.; Roberts, J.; Wood, C. The wilderness expedition: An effective life course intervention to improve young people's well-being and connectedness to nature. J. Exp. Educ. 2016, 39, 59-72. [CrossRef]

90. Wilderness Foundation. Available online: https://wildernessfoundation.org.uk/ (accessed on 1 July 2020).

91. Bragg, R.; Barton, J.; Wood, C. (Eds.) Ecominds Effects on Mental Well-Being. An Evaluation for Mind; Mind: London, UK, 2013.

92. Mind. Ecotherapy Works. Available online: https://www.mind.org.uk/news-campaigns/campaigns/ ecotherapy-works/ (accessed on 1 July 2020).

93. Ahlskog, J.E.; Geda, Y.E.; Graff-Radford, N.R.; Petersen, R.C. Physical exercise as a preventive or disease-modifying treatment of dementia and brain aging. Mayo Clin. Proc. 2011, 86, 876-884. [CrossRef] [PubMed]

94. Dementia Adventure. Available online: https://dementiaadventure.co.uk/ (accessed on 1 July 2020).

95. Jahnke, R.; Larkey, L.; Rogers, C.; Etnier, J.; Lin, F. A comprehensive review of health benefits of qigong and tai chi. Am. J. Health Promot. 2010, 24, e1-e25. [CrossRef]

96. Bhasin, M.K.; Dusek, J.A.; Chang, B.H.; Joseph, M.G.; Denninger, J.W.; Fricchione, G.L.; Benson, H.; Libermann, T.A. Relaxation response induces temporal transcriptome changes in energy metabolism, insulin secretion and inflammatory pathways. PLoS ONE 2013, 8, e62817. [CrossRef]

97. Wayne, P.M.; Fuerst, M.L. The Harvard Medical School Guide to Tai Chi; Shambhala: Boston, MA, USA, 2013.

98. Villemure, C.; Čeko, M.; Cotton, V.A.; Bushnell, M.C. Insular cortex mediates increased pain tolerance in yoga practitioners. Cereb. Cortex 2014, 24, 2732-2740. [CrossRef] [PubMed]

99. Villemure, C.; Ceko, M.; Cotton, V.A.; Bushnell, M.C. Neuroprotective effects of yoga practice: Age-, experience-, and frequency-dependent plasticity. Front. Hum. Neurosci. 2015, 9, 281. [CrossRef] 
100. Kuyken, W.; Hayes, R.; Barrett, B.; Byng, R.; Dalgleish, T.; Kessler, D.; Lewis, G.; Watkins, E.; Brejcha, C.; Cardy, J.; et al. Effectiveness and cost-effectiveness of mindfulness-based cognitive therapy compared with maintenance antidepressant treatment in the prevention of depressive relapse or recurrence (PREVENT): A randomised controlled trial. Lancet 2015, 386, 63-73. [CrossRef]

101. Yang, G.Y.; Wang, L.Q.; Ren, J.; Zhang, Y.; Li, M.L.; Zhu, Y.T.; Luo, J.; Cheng, Y.J.; Li, W.Y.; Wayne, P.M.; et al. Evidence base of clinical studies on Tai Chi: A bibliometric analysis. PLoS ONE 2015, 10, e0120655. [CrossRef]

102. Osypiuk, K.; Thompson, E.; Wayne, P.M. Can Tai Chi and Qigong postures shape our mood? Toward an embodied cognition framework for mind-body research. Front. Hum. Neurosci. 2018, 12, 174. [CrossRef]

103. Walther, A.; Lacker, T.J.; Ehlert, U. Everybody was Kung-Fu fighting-The beneficial effects of Tai Chi Qigong and self-defense Kung-Fu training on psychological and endocrine health in middle aged and older men. Complementary Ther. Med. 2018, 36, 68-72. [CrossRef]

104. Xiang, Y.; Lu, L.; Chen, X.; Wen, Z. Does Tai Chi relieve fatigue? A systematic review and meta-analysis of randomized controlled trials. PLoS ONE 2017, 12, e0174872. [CrossRef] [PubMed]

105. Nisbet, E.K.; Zelenski, J.M.; Grandpierre, Z. Mindfulness in nature enhances connectedness and mood. Ecopsychology 2019, 11, 81-91. [CrossRef]

106. Wang, C.; Li, K.; Choudhury, A.; Gaylord, S. Trends in yoga, Tai Chi, and Qigong use among US adults, 2002-2017. Am. J. Public Health 2019, 109, 755-761. [CrossRef]

107. Fabjański, M.; Brymer, E. Enhancing health and wellbeing through immersion in nature: A conceptual perspective combining the Stoic and Buddhist traditions. Front. Psychol. 2017, 8, 1573. [CrossRef]

108. Duvall, J.; Sullivan, W.C. How to get more out of the green exercise experience: Insights from attention restoration theory. In Green Exercise; Barton, J., Bragg, R., Wood, C., Pretty, J., Eds.; Routledge: Abingdon, UK, 2016.

109. Pagnoni, G.; Cekic, M.; Guo, Y. “Thinking about not-thinking”: Neural correlates of conceptual processing during Zen meditation. PLoS ONE 2008, 3, e3083. [CrossRef]

110. Goleman, D.; Davidson, R.J. Altered Traits: Science Reveals How Meditation Changes Your Mind, Brain, and Body; Penguin: London, UK, 2017.

111. Kotler, S.; Wheal, J. Stealing Fire: How Silicon Valley, the Navy SEALs, and Maverick Scientists Are Revolutionizing the Way We Live and Work; HarperCollins: London, UK, 2017.

112. Csikszentmihali, M. Flow: The Psychology of Happiness; Rider: London, UK, 2002.

113. Brewer, J. The Craving Mind; Yale University Press: New Haven, CT, USA, 2017.

114. Kahneman, D. Thinking, Fast and Slow; Macmillan: New York, NY, USA, 2011.

115. Goleman, D. Focus: The Hidden Driver of Excellence; Bloomsbury: London, UK, 2013.

116. Ricard, M. Happiness: A Guide to Developing Life's Most Important Skill; Atlantic Books: London, UK, 2015.

117. Esch, T.; Fricchione, G.L.; Stefano, G.B. The therapeutic use of the relaxation response in stress-related diseases. Med. Sci. Monit. 2003, 9, RA23-RA34.

118. Dusek, J.A.; Otu, H.H.; Wohlhueter, A.L.; Bhasin, M.; Zerbini, L.F.; Joseph, M.G.; Benson, H.; Libermann, T.A. Genomic counter-stress changes induced by the relaxation response. PLoS ONE 2008, 3, e2576. [CrossRef]

119. Dietrich, A. Functional neuroanatomy of altered states of consciousness: The transient hypofrontality hypothesis. Conscious. Cogn. 2003, 12, 231-256. [CrossRef]

120. Dietrich, A. Transient hypofrontality as a mechanism for the psychological effects of exercise. Psychiatry Res. 2006, 145, 79-83. [CrossRef]

121. Del Giorno, J.M.; Hall, E.E.; O’Leary, K.C.; Bixby, W.R.; Miller, P.C. Cognitive function during acute exercise: A test of the transient hypofrontality theory. J. Sport Exerc. Psychol. 2010, 32, 312-323. [CrossRef]

122. Peres, J.F.; Moreira-Almeida, A.; Caixeta, L.; Leao, F.; Newberg, A. Neuroimaging during trance state: A contribution to the study of dissociation. PLOS ONE 2012, 7, e49360. [CrossRef]

123. Pagnoni, G.; Guareschi, F.T. Remembrance of things to come: A conversation between Zen and neuroscience on the predictive nature of the mind. Mindfulness 2017, 8, 27-37. [CrossRef]

124. Goyal, M.; Singh, S.; Sibinga, E.M.; Gould, N.F.; Rowland-Seymour, A.; Sharma, R.; Berger, Z.; Sleicher, D.; Maron, D.D.; Shihab, H.M.; et al. Meditation programs for psychological stress and well-being: A systematic review and meta-analysis. JAMA Intern. Med. 2014, 174, 357-368. [CrossRef] 
125. Buric, I.; Farias, M.; Jong, J.; Mee, C.; Brazil, I.A. What is the molecular signature of mind-body interventions? A systematic review of gene expression changes induced by meditation and related practices. Front. Immunol. 2017, 8, 670. [CrossRef]

126. Duhigg, C. The Power of Habit; Random House: London, UK, 2012.

127. Ouellette, J.A.; Wood, W. Habit and intention in everyday life: The multiple processes by which past behavior predicts future behavior. Psychol. Bull. 1998, 124, 54. [CrossRef]

128. Verplanken, B.; Melkevik, O. Predicting habit: The case of physical exercise. Psychol. Sport Exerc. 2008, 9, 15-26. [CrossRef]

129. Miltenberger, R.G.; Fuqua, R.W.; Woods, D.W. Applying behavior analysis to clinical problems: Review and analysis of habit reversal. J. Appl. Behav. Anal. 1998, 31, 447-469. [CrossRef] [PubMed]

130. Miltenberger, R.G. Behavior Modification: Principles and Procedures; Cengage Learning: Boston, MA, USA, 2011.

131. Judah, G.; Gardner, B.; Aunger, R. Forming a flossing habit: An exploratory study of the psychological determinants of habit formation. Br. J. Health Psychol. 2013, 18, 338-353. [CrossRef] [PubMed]

132. Gardner, B.; Lally, P.; Wardle, J. Making health habitual: The psychology of 'habit-formation'and general practice. Br. J. Gen. Pract. 2012, 62, 664-666. [CrossRef] [PubMed]

133. Lally, P.; Van Jaarsveld, C.H.; Potts, H.W.; Wardle, J. How are habits formed: Modelling habit formation in the real world. Eur. J. Soc. Psychol. 2010, 40, 998-1009. [CrossRef]

134. Pollan, M. In Defense of Food: An Eater's Manifesto; Penguin: London, UK, 2008.

135. Wilson, B. The Way We Eat Now; Basic Books: New York, NY, USA, 2020.

136. Defra. Food Statistics in Your Pocket; Department for Environment, Food and Rural Affairs: London, UK, 2020.

137. Lang, T. Feeding Britain; Penguin: London, UK, 2020.

138. Barker, F.; Atkins, L.; de Lusignan, S. Applying the COM-B behaviour model and behaviour change wheel to develop an intervention to improve hearing-aid use in adult auditory rehabilitation. Int. J. Audiol. 2016, 55 (Suppl. S3), S90-S98. [CrossRef] [PubMed]

139. West, R.; Michie, S. A brief introduction to the COM-B Model of behaviour and the PRIME Theory of motivation [v1]. Qeios 2020. [CrossRef]

140. NEF. The Economic Benefits of Ecominds; New Economics Foundation: London, UK, 2013.

141. Living Movement. Available online: https://www.livingmovement.com/ (accessed on 1 July 2020).

142. Cheng, M.-C. Master Cheng's New Method of Taichi Ch'uan Self-Cultivation; Hennessy, M., Translator; Blue Snake Books: Berkeley, CA, USA, 1999.

143. Clark, A. The Complete Illustrated Guide to Tai Chi: A Practical Approach to the Ancient Chinese Movement for Health and Well-Being; Barnes and Noble: London, UK, 2001.

144. DCMS. Taking Part Survey; Department for Digital, Culture, Media and Sport: London, UK, 2019.

145. Clark, A.E.; Georgellis, Y. Back to baseline in Britain: Adaptation in the British household panel survey. Economica 2013, 80, 496-512. [CrossRef]

146. Clark, A.E.; Fleche, S.; Layard, R.; Powdthavee, N.; Ward, G. The Origins of Happiness; Princeton University Press: Princeton, NJ, USA, 2018.

147. HM Treasury. Treasury Green Book; HM Treasury: London, UK, 2019.

148. ONS. Measuring National Well-Being, October 2019 Release; Office for National Statistics: London, UK, 2019.

149. Fujiwara, D. General Method for Valuing Non-Market Goods Using Wellbeing Data: Three-Stage Wellbeing Valuation; CEP Discussion Paper No 1233; LSE: London, UK, 2013.

150. Collins, B. How Do We Value Wellbeing? Combining Data to Put an Economic Value on the Change in Short Warwick Edinburgh Wellbeing Scale (SWEMWBS) Scores; University of Liverpool: Liverpool, UK, 2015.

151. Marmot, M.; Friel, S.; Bell, R.; Houweling, T.A.; Taylor, S.; Commission on Social Determinants of Health. Closing the gap in a generation: Health equity through action on the social determinants of health. Lancet 2008, 372, 1661-1669. [CrossRef]

152. Sun, W.; Watanabe, M.; Tanimoto, Y.; Shibutani, T.; Kono, R.; Saito, M.; Usuda, K.; Kono, K. Factors associated with good self-rated health of non-disabled elderly living alone in Japan: A cross-sectional study. BMC Public Health 2007, 7, 297. [CrossRef]

153. Willcox, B.J.; Willcox, D.C.; Ferrucci, L. Secrets of healthy aging and longevity from exceptional survivors around the globe: Lessons from octogenarians to supercentenarians. J. Gerontol. Ser. A Biol. Sci. Med. Sci. 2008, 63, 1181-1185. [CrossRef] 
154. Bergsma, A.; Buijt, I.; Veenhoven, R. Will happiness-trainings make us happier? A research synthesis using an online findings-archive. Front. Psychol. 2020, 11, 1953.

155. Frumkin, H. The Health of Places, the Wealth of Evidence. In Urban Place, Reconnecting with the Natural World; Massachusetts Institute of Technology Press: Cambridge, MA, USA, 2005; pp. 253-269.

156. UNEP. Towards a Green Economy: Pathways to Sustainable Development and Eradication of Poverty; UNEP: Nairobi, Kenya, 2011.

157. Lang, T.; Rayner, G. Ecological public health: The 21st century's big idea? An essay by Tim Lang and Geoff Rayner. BMJ 2012, 345, e5466. [CrossRef]

158. IPCC. Climate Change and Land; IPCC: Geneva, Switzerland, 2019.

159. CCC. Reducing UK Emissions: 2020 Progress Report; Committee on Climate Change, UK Government: London, UK, 2020.

160. Enough Is Enough. Ideas for a Sustainable Economy in a World of Finite Resources; Report of the Steady State Economy Conference; O’Neill, D.W.; Dietz, R.; Jones, N. (Eds.) Centre for the Advancement of the Steady State Economy; Economic Justice for All: Leeds, UK, 2010.

161. Klein, N. This Changes Everything; Penguin: London, UK, 2015.

Publisher's Note: MDPI stays neutral with regard to jurisdictional claims in published maps and institutional affiliations.

(C) 2020 by the authors. Licensee MDPI, Basel, Switzerland. This article is an open access article distributed under the terms and conditions of the Creative Commons Attribution (CC BY) license (http://creativecommons.org/licenses/by/4.0/). 